\title{
The Power Structure of Ondoafi in the Adat Village Government System of Jayapura Regency
}

\author{
Hendrik Krisifu \\ Associate Professor of Faculty of Law, University of Cendrawasih, Papua
}

\begin{abstract}
The aim of this research is to find out the structure of Ondoafi's power and its role in the system of Adat Village Government in Jayapura Regency as a government form based on the Regional Regulation Number 8 of 2016 concerning Adat Village. This research uses normative and empirical research. The results' research indicate that the implementation of the adat village government system with the Ondoafi government system naturally has some structural, administrative and social obstacles. Structurally, the Ondoafi Adat Government has very broad powers/authorities. It has also administrative barrier in terms of supervision from the Regional Government, and of course it will be influenced by the community/social environment as one of the obstacles faced by the adat village government system. The position Ondoafi in traditional governance structure according to the Regional Regulation No. 8 of 2016 has actually run two systems of government, namely the Adat or traditional government system and the customary village administration system that were formed based on the Jayapura Regency Regulation. The new structure of the Adat village apparatus already exists in the Adat governance structure and the Adat functionaries in the Ondoafi system are inherited, hereditary, and sacred. They are responsible for their duties to the ondoafi.
\end{abstract}

Keywords: Ondoafi, Government, Adat Village.

DOI: $10.7176 / \mathrm{JLPG} / 91-08$

Publication date: November $30^{\text {th }} 2019$

\section{Introduction}

Law is a symptom in the reality of a pluralistic society and has many aspects or dimensions. Law is rooted and formed in the process of interaction of various aspects of society (political, economic, social, cultural, technological, religious, etc.). They are formed and in the same time they help to shape the social order. The form of the law itself is generally determined by the community with its various characteristics, and / or vice versa the law also determines the shape and nature of the community itself. So, in its dynamics, the law is conditioned and conditions the community. In this case, the law has a goal to realize order and justice concretely in society. In its implementation, the law requires power and at the same time determines the limits and ways of using that power. ${ }^{1}$

Likewise, customary law is the original law of the Indonesian nation which grows, lives, and develops in indigenous communities in Indonesia. It is one of the sources of positive law used by indigenous peoples in regulating mutual life before Indonesian independence until the Proclamation and still in use today. As the living law, the customary law in its role regulates all aspects of the life of indigenous peoples. One aspect of this is constitutional customary law. According to Bushar Muhammad, Constitutional Customary Law is part of customary law regarding the composition of government, which discusses the aspects of state administration that can be found in customary law. ${ }^{2}$ The constitutional customary law systems are generally found in indigenous peoples throughout the land. The government system in each region has a different term. Some of area states as village, parish, gampong, and kampong. It means that it naturally shows the existence of the Adat government system traditionally and has a position, government structure, organization and positions in it.

The Adat government system as described prior also includes customary law communities in Papua, particular customary law community in the Land Tabi. ${ }^{3}$ It covers areas around Jayapura City, Jayapura Regency, Keroom, and Sarmi. The traditional leadership system in nature is Ondoafi, which is the Head of the Tribe or Clan. In this system, the position of the tribal leader is passed down from generation to generation. In accordance with the development of government reforms in Indonesia, especially the regional autonomy, the regions have the initiative to develop their regions through regional regulations that aim to accelerate regional development for the creation of people's welfare.

The Jayapura Regency Government is also trying to implement the vision of " New Jayapura " by reviving the existence of indigenous peoples as one of the development resources in the Kenambai Umbai Regency which has (indigenous) origin authority. One of the efforts in village development that is carried out

\footnotetext{
${ }^{1}$ Mochtar Kusumaatmadja, Function and Development of Law in National Development (Fungsi dan Perkembangan Hukum Dalam Pembangunan Nasional), Padjadjaran Magazine, in Bernard Arief Sidharta, Reflection Regarding Structure of Legal Science (Refleksi Tentang Struktur Ilmu Hukum), Maju Mandar, Bandung, 2009, p. 116.

${ }^{2}$ Bushar Muhammad, The Basics of the Customary Law (Pokok-Pokok Hukum Adat), Pradnya Paramita, Jakarta 2000, p. 80.

${ }^{3}$ Tanah Tabi means the land of the sun rise.
} 
systematically and has legal responsibility is through regional legal products, which substantially authorize the government and village community to be actively involved in village development, through granting authority to the village as broad as possible; financial planning; village development planning and village legislation authority.

One of the efforts is to shape the Adat Village. It is a system of the adat village government established by Jayapura Regency Government based on Jayapura Regency Regional Regulation No. 8 of 2016 concerning the Adat Village. It is a merger between the adat government system and the village government system. The purpose of the establishment of the Regional Regulation of the Adat Village can be seen in Article 3, as followings:

a. Strengthening the role of the adat village government in the system of governance and regional development;

b. Preserving and protecting of the customs and traditions that are alive and must be maintained in the community for generations; and

c. Giving more space to the adat village government in the administration of governance and regional development and services to the community.

In addition, in the second paragraph of the general explanation of the adat village regulation, it is stated that this regional regulation gives a slight difference between a village and an adat village. This is intended to show that the existence of Papuans and their traditional rights will continue to be recognized and respected in the administration of regional government. The villages that have been formed and already exist in the Jayapura Regency area need to be classified and given a clear status that is given the naming as the adat villages and villages, so as not to cause confusion in understanding and achieving targets for regional development in the implementation of the Special Autonomy of Papua. This Regional Regulation also regulates the mechanism for the formation of the adat villages which will be regulated by Regents Decree. In the adat village there is no structure like in the village that is village consultative body (BAMUSKAM). This is because the adat village embracing system of traditional leadership that is Ondoafi or other designations adopted by each tribal region Jayapura regency, thereby impose an institutional model which will exercise control over the administrators of the village - called the Council of Adat Villages that its members derived from Tribal Heads of each tribe in the adat leadership system adopted by the Adat Village Government.

Article 1 Number 1 the Law No. 6 of 2014 on the village states that the village is village and Adat village or the so-called village, is the unity of the legal community who have boundaries that are authorized to regulate and manage the affairs of government, the interests of the local community by community initiatives, original rights, and/or traditional rights that are recognized and respected in the system of government of the Unitary Republic of Indonesia. Article 96 then confirms that the Government, Provincial Government, and Regency / City Government make the arrangement of customary law community units and are determined to become Adat Villages.

Regarding to an administrative of Adat Government traditionally, Ondoafi has hierarchy gradually and hereditary. According to JR Mansoben, the system of government/leadership in the Sentani indigenous community is that the leadership system is the Head of Clan or Ondoafi. The main characteristic of this system is that the leadership position is inherited based on seniority; power exercised by a body with a clear division of tasks; the source of power is based on heredity and religion; power manifested in control of land, water and the sources of community life; community leaders and concurrently as leaders of religious ceremonies. ${ }^{1} \mathrm{~A}$ person who is an Ondoafi has very broad authority because it covers all aspects of life in his village including the fields of religion, economy, social welfare, security and justice. ${ }^{2}$

In the implementation of administrative of Adat Government with a system of government ondoafi, there will be obstacles structural, administrative, and social. In the structure of the adat government, ondoafi has the power / authority is very broad. In terms of the administration of government the formal supervision of the Local Government and also environment of indigenous communities /social. In the context of the adat village, Ondoafi has very broad authorities including legislative, executive, and judicial powers. However, in terms of traditional structures actually Ondoafi monitored and restricted and no longer has absolute power over its own communities and Ondoafi no longer be the leader of the "free" in the nature of Adat.

\section{Literature review}

\subsection{Theory of Indonesian State Law}

According to Muhammad Yamin, Indonesia is a state of law (rechtsstaat, goverment of law) which carries out the justice written in the law made by legitimate state bodies and which receives temporary surrender from the

\footnotetext{
${ }^{1}$ Joshz Mansoben, Diversity of Leadership Systems in Irian Jaya Province, in Yulfita Raharjo (ed.), Proceedings on Building Irian Jaya Communities (Kebinekaan Sistem Kepemimpinan Di Pronvinsi Irian Jaya, dalam Yulfita Raharjo (edt), Proseding Membangun Masyarakat Irian Jaya), Puslitbang Kependudukan dan Ketenagakerjaan Lembaga Ilmu Pengetahuan Indonesia (PPT-LIPI), Jakarta, 1995 , p. 102.

${ }^{2}$ Ibid., p. 107.
} 
highest authority at the hands of the Indonesian people. In the rule of law of the Republic of Indonesia, citizens are governed and treated by justice laws made by the people themselves, in a legal way according to conditions that can be investigated or monitored by the people themselves. ${ }^{1}$ Because of the affirmation of Indonesia as a state of law written in the State Constitution, Muhammad Yamin's view is based on the principle of legality. In this context, written law or law becomes important as a source of law in the rule of law. It means that something outside the law is not law. Muhammad Yamin's opinion as mentioned above are the views of a positivistic legal expert at the beginning of the independent Indonesian state.

Unlike Muhammad Yamin, Mochtar Kusumaatmadja and Arief Sidharta provide the main characteristics of the ideals of the law ( rechts-idee ) of the Republic of Indonesia, namely: first, it is in the rule of law, power is not unlimited. It means that power is subject to law. Popularly it can be said that the rule of law is a state based on law, where power is subject to law; second, in the rule of law all people are equal before the law. In other words, the law treats all people equally without distinction based on race (ancestry), religion, social position and wealth. ${ }^{2}$

After the third amendment to the 1945 Constitution of the Republic of Indonesia in 2001, in Chapter I the Form and Sovereignty, Article 1 paragraph (3) is determined expressly that "The State of Indonesia is a state of law". In the concept of the rule of law, it is idealized that what must be commander in the dynamic of state life is law, not politics or economics. ${ }^{3}$ Mahfud MD states the principle of the rule of law as stipulated in article 1 paragraph (3) in neutral terms (without mentioning Rechtsstaat or the rule of law) which reads exactly "the State of Indonesia is a state of law". ${ }^{4}$

Previously, from the history of the Constitution of the Republic of Indonesia, the provisions regarding the Indonesian Law State were expressly stated in the formulation of the Republic of Indonesia United (RIS) Constitution (UUD RIS) of $1950,{ }^{5}$ in the Preamble section of the fourth paragraph it is stated, that to realize happiness, prosperity, peace and independence in a free and sovereign and perfect Indonesian law and society. In the Torso of the Constitution, it is affirmed in Article 1 (1) of the RIS that the free and sovereign state (RIS) is a democratic constitutional state and the shape of the Federation.

Likewise in the Provisional Constitution of 1950, it is emphasized in the fourth paragraph in the preamble section that "for this sake of independence, it is formed in a charter in the form of a republic - unity, based on the recognition of the Almighty God, humanity, nationality, society, and social justice, to realize happiness, prosperity, peace and independence in society and the rule of law of independent of Indonesia. Article 1 paragraph (1) determines that an independent and sovereign Republic of Indonesia is a democratic and unitary state of law. ${ }^{6}$

Both of the constitutions mentioned above clearly state Indonesia as a state of law. The notion of the rule of law / rechtsstaat is often associated with the notion of "democratic". So that is an ideal in a state is a democratic rule of law (democratic rectstaat), the formula used in the RIS Constitution and the Provisional Constitution of 1950 is a formula commonly used in the western world in a parliamentary system.

\subsection{Theory of Customary Law}

2.2.1. Customary Law Alliance

According to Ter Haar, throughout the Indonesian archipelago at the level of the common people, there is a social life in the groups that behave as a unity to the world of birth and mind. These groups have a fixed and eternal arrangement and the people in each group experience their lives in that group as appropriate, according to nature's nature. None of them had any thoughts about the possibility of disbanding the group. This group has its own management, own property, worldly possessions and supernatural property. ${ }^{8}$ So the Alliance is a unit that has an orderly and eternal arrangement and has its own management and own wealth, both material wealth and

\footnotetext{
${ }^{1}$ Sudargo Gautama, Definition of State Law (Pengertian Tentang Negara Hukum), Alumni, Bandung, 1973, p. 23.

${ }^{2}$ Mochtar Kusumaatmadja and Arief Sidharta, Introduction to Legal Studies: A First Introduction to the Scope of Applicability to Legal Studies (Pengantar Ilmu Hukum Suatu Pengenalan Pertama Ruang Lingkup Berlakunya Ilmu Hukum), Buku I, Penerbit Alumni, Bandung, 2000, p. 134

${ }^{3}$ Jimly Asshiddiqie, Principles of Indonesian Constitutional Law Post Reformation (Pokok-Pokok Hukum Tata Negara Indonesia Pasca Reformasi), PT Bhuana Ilmu Populer, Jakarta, 2007, p. 297.

${ }^{4}$ Moh. Mahfud MD, Building Political Law, Upholding the Constitution (Membangun Politik Hukum, Menegakkan Konstitusi), LP3ES, Jakarta, 2006, p. 27.

${ }^{5}$ See RIS Constitution, valid based on the President Decree Number 48 of 1950 concerning the promulgation of the Charter of the Republic of Indonesia Constitution, dated January 31. It was announced in Jakarta on 6 February 1950 by the Minister of Justice. (State Gazette Number 3 of 1950).

${ }^{6}$ See Provisional Indonesian Constitution (UUDS) applies Under Law Number 7 of 1950 concerning Amendments to the Provisional Constitution of the United States of Indonesia into a Provisional Constitution of the Republic of Indonesia. It was announced in Jakarta on August 15, 1950 by the Minister of Justice (State Gazette No. 56 of 1950).

${ }^{7}$ Padmo Wahyono, Indonesia is based on law (Indonesia Negara Berdasarkan Atas Hukum), Ghalia Indonesia, Jakarta 1986, p. 8.

${ }^{8}$ Soerojo Wignjodipoera, Introduction and Principles of Customary Law (Pengantar dan Asas-Asas Hukum Adat), Penerbit Toko Gunung Agung, Jakarta, 1995, p. 77.
} 
immaterial wealth. ${ }^{1}$

2.2.2 Customary Government Systems

According to Hilman Hadikusuma, customary law on constitutional law is original Indonesian law that is not written in the form of Indonesian legislation concerning the constitutional field. ${ }^{2}$ The focus of the system is on the various forms of customary law associations found among the people, especially traditional customary law associations and similarly developed forms, insofar as they are customary law associations, which are found in Indonesia. $^{3}$

\section{2..3 Customary leaders}

In the traditional Indonesian school of thought, the legal alliance is as a collectively in which each citizen feels himself one with the whole group.Therefore, the head of the alliance is the head of the people and the father of the community. He know the fellowship as chairman of a large family. The head of the people is tasked with maintaining harmony in the fellowship, so that the law can run properly.

People's activities basically include 3 things as follows:

1. Closing actions between the land and the fellowship that rules the land;

2. Implementation of law as an effort to prevent violations of the law; so that the law can work as it should (preventive guidance); and

3. Carrying out law as legal correction after the law was violated (repressive coaching).

The task of maintaining or administering the law of the head of the people covers all fields of customary law. ${ }^{4}$

\subsection{Ondoafi's Concept and Structure}

\subsubsection{Ondoafi}

Ondoafi in Sentani language is called Ondofolo, or the same as the language of the Teluk Ondewafi / Yo Warepo bay land. The Nimboran / Nambloung language is known as Iram or hlu dekening which is the same as the Moi Done or Trang languages in Kemtuk and Gresi languages. ${ }^{5}$ The leader in the Sentani customary law community is called Ondoafi. According to Joshz Mansoben, the government/leadership system in the Sentani customary law community is the leadership system is the Head of Clan or Ondoafi. The main characteristic of this system is that the leadership position is inherited based on seniority; power exercised by a body with a clear division of tasks; the source of power is based on heredity and religion; power manifested in control of land, water and the sources of community life; community leaders and concurrently as leaders of religious ceremonies. ${ }^{6}$ A person who serves as Ondoafi has broad powers as it covers all aspects of life in the village include the fields of religion, the economy, social welfare, security and justice. ${ }^{7}$

2.3.2. Ondoafi Structure

This type of leadership is supported by ethnic collectives in northeastern Papua, all of which are in Jayapura Regency. Some examples of residents supporting the system are the Sentani people (in and around Lake Sentani), the Tobati people (in Yos Sudarso bay or formerly the Humbolt bay), the Genyem people or the Nimboran people (on the Grime river plain located west of Lake Sentani), the people Tabla (in the Tanah Merah bay and west of the Cycloop mountain), Skow people (on the north coast west of the boundary line of the Papua Province with the State of Papua New Guinea). The Arso and the Waris (in the upper reaches of the Tami river) and the Demta people are on the north coast between the Muris village to the east and the Demta village to the west. ${ }^{8}$

The government/leadership system in the Sentani customary law community is the leadership system is the Head of Clan or Ondoafi. The main characteristic of this system is that the leadership position is inherited based on seniority; power exercised by a body with a clear division of tasks; the source of power is based on heredity and religion; power manifested in control of land, water and the sources of community life; community leaders and concurrently as leaders of religious ceremonies. ${ }^{9}$ A person who is an ondoafi has very broad authority because it covers all aspects of life in his village including the fields of religion, economy, social welfare, security and justice. ${ }^{10}$

In the religious field, the Ondoafi must oversee and maintain the civilized life and religious ceremonies in his village community, such as leading the initiation rituals and leading the ceremonial payment of the skull /

\footnotetext{
${ }^{1}$ Ibid, p.78

${ }^{2}$ Hilman Hadikusuma, Customary Administrative Law (Hukum Ketatanegaraan Adat), Alumni, Bandung 1981 , p.1.

${ }^{3}$ Ibid. p.3.

${ }^{4}$ Soerojo Wignjodipoera, op.cit., p. 92.

${ }^{5}$ Badan Penelitian dan Pengembangan Daerah Kabupaten Jayapura, The Role of Ondoafi between the Modern State and the New "Religions" (Peran Ondoafi yang Terapit antara Negara Modern dan "Agama-Agama" Baru). Delivered in Socialization of the Role of Ondoafi in Jayapura, 2013, p.3.

${ }^{6}$ Joshz Mansoben, op.cit., p. 102.

${ }^{7}$ Ibid., p. 107.

${ }^{8}$ Ibid., p. 90.

${ }^{9}$ Ibid., p. 102.

${ }^{10}$ Ibid. p.107
} 
head payment. Ondoafi is obliged to activate the customary life of members of his community through supervision of the attitude of courtesy in daily exchanges between members of his community, and supervision of the intensification of traditional ceremonies in his sphere of authority. ${ }^{1}$

In the economic field, its role as holders of inheritance over village assets is reflected; 1) heirlooms, such as stone bracelets or (Ebha), beads or (Nokhom and Eve) and stone axes. These objects are prestige objects that are only owned by Ondoafi and may not be owned by other members of the community. Because the objects give a certain status to the owner both in the eyes of his own people and in the eyes of other leaders; 2) natural resource wealth. Ondoafi has the authority to give permission to seek, use or utilize existing natural resources for people's welfare lives. And also supervise the exploitation of natural resources. ${ }^{2}$

Ondoafi's authority in the social sphere is reflected in several things: 1) the right to receive a portion of the dowry property of each girl from her village who marries in the village. The treasure is usually used by Ondoafi for the benefit of the people. For example if a community member is subject to a customary fine due to a certain violation against a community member from another village, then Ondoafi helps pay a portion of it using the treasury from the village treasury. Likewise, it is also to pay the dowry of each boy from his village who marries a girl from another village ; 2) the right to get the most from hunting or fishing and the first harvest from the garden. Such authority in indigenous peoples is expressed by the term " Tali ondofolo, waya ondofolo" which means that Ondofolo in general he does not only look into his village, but also looks out for the welfare of other villages. ${ }^{3}$ The results obtained are then distributed to members of the community under his control or to other villages.

In the field of security and order, Ondoafi has the authority to act both inside and outside. The authority Ondoafi to act in was the right and duty to maintain security and order in society by way of reprimand, punish, and even eliminate their own community members are found to violate the provisions of the customs and dangerous to public safety in the community. Furthermore, the authority to leave is the right to declare war with other hostile villages. ${ }^{4}$

Ondoafi's authority in the field of court is reflected in his position as a judge in charge of resolving disputes arising between residents of different villages / tribes in his authority. ${ }^{5}$ Ondoafi's broad authority as contained in the descriptions above is summed up in a phrase : Ondofolo yo longgo, obo isolo-ro isolo. The phrase means: " Ondofolo is a banyan tree that protects the community, and all prosperity of the village must be returned to ondoafi because all matters and death are his responsibility."

\subsection{Village and Traditional Village}

The existence of the existing village government is a legacy from the old law that ever existed, which governs the village, namely Inlandsche Gemeente Ordonantie (IGO) (Stb. 1906 Number 83) that applies to Java and Madura and Inlandsche Gemeente Ordonantie Butengewesten (IGO) ( IGO) (Stb. 1906 Number 83) that applies to Java and Madura and the Inlandsche Gemeente Ordonantie Butengewesten (IGO) (IGO) ( Stg . Stl. 1938 Number 490 jo Stl. 1938 Number 681) which applies to outside Java and Madura.

In the legislation, it does not regulate village government uniformly and does not provide enough impetus for the community to grow toward dynamic progress. As a result, the village and the existing village administration still have a variety of forms and patterns, each region has its own characteristics, which sometimes are obstacles to intensive guidance and control in order to improve the standard of living of the community. According to Bayu Surianingrat, it cannot be known with certainty when the village began. ${ }^{6}$ Each region uses terms with various names, for example; Kampung (West Java), Gampong (Aceh), Huta or Kuta (Tapanuli), Marga (South Sumatra), Negeri (Maluku), Nagari (Minangkabau), Hamlet (Lampung), Wanua (Minahasa), Gaukay (Makassar) and Kampung (Papua).

Then, on December 1, 1997 Law No. 5 of 1997 concerning Village Government (the Law on Village Governance or UUPD) was enacted hereinafter referred to as the Village Law. This Village Law leads to the uniformity of the form and composition of village government with a national style that guarantees the realization of Pancasila Democracy in a real way, by channelling people's opinions in a container called the Village Deliberation Institute.

Villages according to Law Number 6 of 2014 concerning Villages Article 1 number 1 states that Villages are villages and traditional villages or referred to by other names, hereinafter referred to as Villages, are legal community units that have territorial boundaries authorized to regulate and administer government affairs. The

\footnotetext{
${ }^{1}$ Ibid.

${ }^{2}$ Ibid.p. 108.

${ }^{3}$ Information provided by Neles Modouw.

${ }^{4}$ Joshz Mansoben, op.cit., p. 108

${ }^{5}$ Ibid.

${ }^{6}$ Bayu Surianingrat, Village Government and Administration (Pemerintahan dan Administrasi Desa), Yayasan Beringin Korpri Unit Departemen Dalam Negeri, Jakarta, 1976, p. 1.
} 
interests of the local community are based on community initiatives, origins, and / or traditional rights that are recognized and respected in the system of government of the Unitary Republic of Indonesia. Article 6 paragraph (2) further mention a village or customary village is adjusted to the mention that applies in the local area. The villages and traditional villages are regulated by Government Regulation No. 43 of 2014 concerning the Implementation of Law No. 6 of 2014 concerning Villages.

\subsection{Kampung and Adat Kampung}

According to Law Number 21 of 2001 concerning Special Autonomy for the Province of Papua in Article 1 letter 1 mentiones Kampung or what is referred to by other names is the legal community unit whose authority is to regulate and manage the community's interests based on local origins and customs which are recognized in the national government system and are located in the Regency / City area. And in Article 3 paragraph (3) it is mentioned that the district consists of a number of Kampung or referred to by other names.

The Law Number 21 of 2001 has been derived to Jayapura Regency Regulation Number 8 of 2016 concerning Adat Kampung. However, the Regional Regulation does not provide a definition of what is an Adat Kampung. Article 1 number 6 states that the Adat Kampung Government is an Ondoafi or other designation with the apparatus which has been formed from generation to generation. Article 1 number 7 mentions further that the Adat Kampung Government is the Head of the Customary Village and his ranks are appointed by the Adat Kampung Government.

The Adat Kampung in Jayapura Regency was formed by the Jayapura Regency Regional Regulation Number 8 of 2016 concerning Adat Kampung. The Adat Kampung is a merger (adoption) between the adat government system and the village government system. Article 5 in the Regional Regulation Number 8 of 2016 contains the characteristics of the adat kampung, as followings:

a. Having indigenous groups and inhabited areas;

b. Having genealogical relations;

c. Having territorial and / genealogical unitary territorial integrity;

d. Some or all members of indigenous peoples still use local / mother tongue languages;

e. Having customs and customary law still apply to local indigenous peoples;

f. Having traditional leadership patterns that are still alive based on local customs;

g. Having traditional customary rights inherited from generation to generation; and

h. Having customary justice.

One of the efforts of the Jayapura Regency Government in implementing Law Number 6 of 2014 concerning Villages with local conditions that still use the adat government system is the Ondoafi System. So the Jayapura Regency Government made Jayapura Regency Regulation Number 8 of 2016 concerning The Adat Kampung. In the preamble of the Regional Regulation Number 8 of 2016, section considering - letter d - states that the provisions of Article 101 of the Village Law authorize the Regency / City Government to arrange the Customary Village (Village) through the Regency / City Regulation.

In the general explanation of Regional Regulation No. 6 of 2014, it is explained that in the provisions of Article 18 paragraph (1) and paragraph (2), the 1945 Constitution of the Republic of Indonesia regulates that the Unitary State of the Republic of Indonesia is divided into regency and city areas, each province, district and city has regional government, which is regulated by law. Provinces and districts are given the authority to regulate and manage their own government affairs according to the principle of autonomy and assistance tasks. Based on this regulation, Jayapura Regency also has the authority to regulate levels of government such as the District and Kampung. The existence of indigenous peoples is guaranteed in Article 18B paragraph (1) of the 1945 Constitution of the Republic of Indonesia. For the Province of Papua, the intended community resides in the Village, because the Village is a legal community unit that has the authority to regulate and manage the interests of the local community based on their origin and local customs recognized in the national government system. On the basis of guarantees recognized in the national government system. On the basis of constitutional guarantees, for the Kampung in the Jayapura Regency region which is largely populated by indigenous peoples, it needs to be protected, empowered by its existence in the administration of governance and regional development. Bearing in mind that the villages formed by using Government Regulation Number 72 of 2005 concerning Villages, do not necessarily strengthen and protect the existence of indigenous peoples and their traditional rights through Kampung organizations and empower and strengthen the participation of indigenous peoples in the implementation of national development. In addition, the community is guaranteed its existence by the Regional Government through providing opportunities to manage the potential of natural resources owned and local wisdom in the socio-cultural life of the community, in order to support the acceleration of the achievement of people's welfare.

This regional regulation gives a little difference between Kampung and Adat Kampung. This is intended so that the existence of Papuans and their traditional rights will continue to be recognized and respected in the administration of regional government. The villages that have been formed and already exist in the Jayapura 
Regency area, need to be classified and given a clear status that is given the naming as Kampung and Adat Kampung, so as not to cause confusion in understanding and achieving targets for regional development in the implementation of the Special Autonomy of Papua. This Regional Regulation also regulates the mechanism for the formation of Adat Kampung which will be regulated by Regents Decree. In the Adat Kampung there is no structure like in the village that is BAMUSKAM. This is because the Adat Kampung adheres to the traditional leadership system - called Ondoafi or other designations adopted by each tribe in the Jayapura district area, so an institutional model that will exercise Control over the Implementation of the Village Government is called the Kampung Adat Council whose membership comes from the Head -Head of each tribe in the traditional leadership system adopted by the Adat Kampung Government.

In the Adat Kampung, the selection of the Head of the Adat Kampung is carried out through negotiation by members of the the adat kampung community consisting of tribes and clan. Thus the procedure for electing the Head of the Adat Kampung is different from the Head of the Kampung who is elected by voting.

For the Papua Province, Law No. 21/2001 concerning Special Autonomy for the Papua Province has been enacted. The principle of special autonomy is the granting of broader authority to the Province and the people of Papua to regulate and manage themselves within the framework of the Unitary State of the Republic of Indonesia. On the basis of the enactment of Special Autonomy, the arrangement of the existence of Kampung Government needs to be done to provide legal certainty and clarity in the administration of regional government in Jayapura Regency, so that the existence of indigenous Papuan people who are also Papuans can be protected, empowered and there is a partiality policy implemented by the Regional Government towards communities in Jayapura Regency.

The existence of Indigenous people to be respected and protected by their customary rights as mandated in Article 43 of Law Number 6 of 2014 concerning Villages/Adat Kampung which is an embodiment of the existence of Kampung in Jayapura Regency whose existence is increasingly weak due to the enactment of Government Regulation Number 72 of 2005 concerning Village.

In the explanation of Article 14 of the the Adat Kampung Regulation, the form of governance of the Adat Kampung referred to by another designation is:

a. Ondofolo for the Sentani region;

b. Ondewafi for the Tepra and Yokari regions;

c. Tube for Ormu region;

d. Done dfor the Moi region;

e. Mrar Matawun, Matawun Pan and Mran Tamsu for the Jouw, Wari and Tarpi regions;

f. Dugeno or Kikeno or also called Dugu for the Gresi and Kemtuk regions;

g. Iram for the Namblong region; and

h. Octim for the regions of Orya, Elseng, Sause, Kaureh, Nakasai, Kapaouri and Kosare.

\section{Research methods}

The approaches used in this study are normative and empirical juridical. The normative approach is carried out by using legal material in the form of relevant laws and regulations. The empirical approach was carried out by analysing primary data from the field regarding interactions and views between adat / Ondoafi leaders, communities, and Regional Governments (districts and local governments) in implementing The Regional Government No 6 2016. Primary data are obtained in Jayapura District by taking the sample of Kampung Ayapo District Sentani Timur, Kampung Ketemum, Genyem District, and Ormu Wari Village, Revirara District. The data obtained are then analyzed qualitatively.

\section{Results and Discussion}

4.1. Position of Ondoafi's Power Structure in the Adat Village Government System in Jayapura Regency Jayapura Regency has 19 districts, 5 villages and 139 Kampung. Based on the Decree of the Regent of Jayapura No. 1884 / 450 of 2016 dated 16 December 2016, it recognizes 37 (thirty-seven) Adat Kampung in Jayapura Regency. Regional Government of Jayapura Regency in its effort to implement Law Number 6 of 2014 concerning Villages has enacted the Jayapura Regional Regulation Number 8 of 2016 concerning Adat Kampung. The regulation is aimed to encourage the formation of the Adat Kampung throughout the customary territories in Jayapura Regency. Article 2 of this Regulation affirms that the established of this Regional Regulation is intended as an attempt to organize the Adat Kampung, the Adat Kampung government, adat discussion forum, and customary justice in order to optimize its role in governance and development of the Adat Kampung and services to indigenous peoples. The objective of establishing the Adat Kampung as mentioned in Article 3 of this regulation is to:

a. Strengthen the role of the Adat Kampung government in the system of governance and regional development;

b. Preserve and protect of the customs that live and are maintained in society for generations; and 
c. Give more space to the the Adat Kampung government in the administration of governance and regional development and services to the community.

In addition to the objectives referred to in the Regional Regulation above, the purpose of establishing the Adat Kampung also has social and political objectives that are affirmative action in providing partiality, empowerment and protection for Papuans along with their traditional rights that have existed for generations. The establishment of the Adat Kampung in Jayapura Regency will certainly have structural obstacles in the customary, administrative and social governance of indigenous peoples. Structurally, in adat government, it has very broad powers / authority. In terms of formal government administration, there is supervision from the Regional Government and also of course obstacles from the environment of indigenous / social communities.

Ondoaf $i$ is the head of the village and the head of the customary government in the village. Ondoafi led several tribes in a village, but Ondoafi does not play an active role in the administration of village government. Those who play an active role in carrying out village / customary government are the tribal chief or khoselo. Position Ondoafi is a position that is the inheritance and must be in line with the founder of the village. It means that he is the eldest son of Ondoafi before. Whereas the position of Ondoafi will only be transferred to the eldest son if the previous Ondoafi is no longer able to carry out his duties because of old age, illness. or has died.

At first, a Ondofolo rules over a village which is a single ethnic group culture and have unity of origin. (The village in Sentani is called " yo "). The conditions for having one village (yo) are:

1. Clear boundaries (boundaries and rights to land and water).

2. There is a community, consisting of layers :

a. Ondofolo - Kose (Ondofolo - Koselo)

b. Akha - Pakhe (ordinary people - relatives).

3. Ondofolo has " Kuiphea " which is the values / attributes of greatness, symbolizing the existence of an Ondofolo and means there is yo. There is no Ondofolo without yo and no yo without Ondofolo. " Kuiphea " is a symbol of the dignity and sovereignty of Ondofolo. Kuiphea is :

a. Eba (stone bracelets) and hembuni feather (beaded ropes).

b. Hiyakhe (paradise bird feather).

c. Obo isolo - ro isolo (all village prosperity must be returned to Ondofolo and all cases and deaths are the responsibility of Ondofolo). ${ }^{1}$

In the Sentani traditional government law, Ondoafi has a structure of power / authority and customary functionaries who carry out traditional customary day-to-day governance that has existed for generations and the functionary position is inherited. Structure and responsibilities of functionaries who help carry out the duties of adat government, namely;

1) Khoselo or head of tribe;

2) Yonow or the Customary Council;

3) Abu Afa - Ayofa nolofa or representative / protector ;

4) Abu Afa - Meakhban nolofa or treasurer;

5) Pulo Yo or religious / religious affairs;

- Uwfoi or protector of magical arts.

6) Come on Phulo or security matters;

- Phulo phalayum or war leader.

7) Phume-Ameyo or welfare matters;

- Fi-yo or special officers regulate and oversee the activities of gathering sago;

- Buyo-kayo or special officer regulates and supervises fishing in lake waters in the village environment;

- Aniyo-erayo or special officer regulates and oversees forest use;

- Yayo or special officer regulates and supervises raising livestock and hunting wild animals;

- Buroyo or special officers treat sick people and help women who experience difficulties during childbirth;

8) Yomme-Yammeyo or matters of order

- Dali Ondofolo

- Wai Ondofolo

Each functionary is responsible for his area of duty in assisting Ondoafi in carrying out the wheels of adat government in the village. Ondoafi with the structure and customs functionaries who thus make Ondoafi as village leaders to power/to treatment early are very spacious on customary community covering all aspects of life in the village include the fields of religion, the economy, social welfare, security and justice. Ondoafi also

${ }^{1}$ Willem Malowali, The System of Ondofolo Governmnet: some Notes to Amendments as resulted ofImplementation of Governemnt System Based on The Law No. 5 of 1979 (Sistem Pemerintahan Ondofolo; Beberapa Catatan Tentang Perubahan-Perubahan yang terjadi sebagai akibat dari Pelaksanaan Sistem Pemerintahan Berdasarkan Undang-Undang Nomor 5 Tahun 1979), Jayapura,1986, p. 5. 
rules over all natural resources both on land and at sea.

For example, Ondoafi authorities in the social sphere is reflected in : 1) the right to receive a portion of the property dowry of any girl of its Kampung who married in the Kampung. The treasure is usually used by Ondoafi for the benefit of the people. For example if a community member is subject to a customary fine due to a certain violation against a community member from another village, then Ondoaf helps pay a portion of it using the treasury from the village treasury. Likewise, it is also to pay the dowry of each boy from his village who marries a girl from another village; 2) the right to get the most from hunting or fishing and the first harvest from the garden. Such authority in indigenous peoples is expressed by the term " Tali ondofolo, waya ondofolo" which means that ondofolo in general he does not only look into his village, but also looks out for the welfare of other villages. ${ }^{1}$ The results obtained are then distributed to members of the community under his control and to other villages. Ondoafi is likened to yolonggo or a protective banyan tree. Ondoafi is a symbol of the sovereignty of a Kampung and a value stem in its community .

Thus, if we compare the position of the traditional governance structure of Ondoafi, according to the Regional Regulation of Jayapura Regency No. 8 of 2016, actually Ondoafi run two systems of government, namely; Kampung governance system sas mentioned in Article 1 number 13, number 14, number 15 and number 16. In addition, the head of Kampung position is limited to six (6) years including their officials (vide Article 35). The Adat Kampung apparatus is the supporting element of the Adat Kampung Head consisting of the Village Secretary, the Village Treasurer, the field technical implementer and the territorial element (vide Article 26). All apparatus already exist in the adat Kampung government structure that is traditional and is inheritance and heredity in which it is sacred and they are responsible for the duties to Ondoafi.

Besides that, there are new responsibilities that were introduced through the Adat Kampung Law as stated in Article 39, namely: Head of the Adat Kampung develop a village development plan together with the community through adat kampung meetings; carry out kampung development together with the community; managing finance kampung from government and local authorities are responsible, transparent and accountable; and bubmitting accountability reports regarding the implementation of development and financial management to local governments.

On the side of kampung development planning and financial management, Ondoafi or the head of the adat kampung government are given responsibility for preparing the adat kampung program and budget plan and then the head of the adat kampung is also held accountable for the kampung development program and financial management is examined by authorized and certified examiners and the results of kampung development, and the results of financial management checks are reported to the Regent (vide Article 34, Article 65, Article 69, Article 70 and Article 71).

The Position of Ondoafi's Power Structure in the Adat Kampung Government system in Jayapura Regency based on the Jayapura Regency Regulation No. 8 of 2016 shows that the traditional Ondoafi structure that has been going on for generations has not changed. However, through the Adat Kampung Law, Ondoafi is given additional functionaries in the adat kampung structure, namely secretaries and treasurers who were actually in the functionary structure of the convergence of such functionaries. Another thing is that the Ondoafi must be responsible for developing the Kampung administratively and financially to the district head or regional government. Whereas administrative government in the Regional Regulation does not appoint an Ondoafi as the head of the adat kampung government to carry out his duties and functions as an organ in the government system.

\subsection{The role of d late Function Ondoafi d nature of Indigenous Village Governance System in Jayapura}

The head of the alliance is the head of the people and the father of the community. He know the fellowship as chairman of a large family. The head of the people is tasked with maintaining harmony in the fellowship, so that the law can run properly. People's activities basically include 3 things, as follows:

a. Closing actions between the land and the fellowship that rules the land.

b. Implementation of law as an effort to prevent violations of the law; so that the law can work as it should (preventive guidance).

c. Carrying out law as legal correction after the law was violated (repressive coaching).

The task of maintaining or administering the law of the head of the people covers all fields of customary law. ${ }^{2}$

Similarly in the government system, Ondoafi has three main roles, namely: 1. Protectors; 2. Prosperous; 3. Preserver. The first role is carried out through the functions of defence of security, welfare, health and religious / religious belief systems; The second role is carried out through the socio-economic system suitable for planting, taking basic foodstuffs, complementary foods and substitute foods (sago, tubers, vegetables, fish, meat / animal protein from the natural environment carried out by members of the household eye or household then distributed through the ondoafi house which is also the place for the decision to share the results to those who are entitled to

\footnotetext{
${ }^{1}$ Information provided by Neles Modouw.

${ }^{2}$ Soerojo Wignjodipoero, op.cit, p. 92.
} 
obtain it. The third role is carried out through the function of taking care of marriage (with efforts to establish relations outside and into the customary environment) in accordance with the position, status and function of people in their customs so that there is no disruption in kinship relations and functions within the customary state are not disturbed. ${ }^{1}$

From the Jayapura Regency Regional Regulation on Adat Kampung, in Article 18 paragraph (2) emphasizes that the duties and functions of the administration of the adat kampung include realizing the welfare of members of the adat kampung community through the administration of customary village governance. It is to:

a. lead indigenous peoples in one or more adat kampung in accordance with the adopted traditional governance system;

b. implement and uphold customary values and norms that apply in indigenous peoples;

c. conduct customary justice to resolve customary disputes and customary offenses that occur to the lead adat community;

d. lead the administration of customary village governance; and

e. assist the government and regional governments in the administration of government and regional development and services for indigenous peoples.

The head of the people or the head of the customary government in the customary law system in Indonesia in carrying out their duties, functions and responsibilities is voluntary, as is the case with Ondoafi . However, in the adat kampung administration system according to the Jayapura Regency Regional Regulation, Article 33 states; The Government of the adat kampung in carrying out its duties and authorities, is given the right in the form of incentives by the local government. This shows that there is something new that is practiced in the adat kampung administration system.

\section{Conclusion}

It can be concluded that in the context of the Ondoafi structure, its role and function in the Adat Kampung Government System in Jayapura Regency which is regulated by Jayapura Regional Regulation No 8 of 2016 . It shows that there is a new structure, role and function given to ondoafi. The new structure, role and function places a burden on the Ondoafi in carrying out his duties and functions as the traditional head of government and the adat kampung administration system which is formed by the regional government. The new duties and responsibilities, besides appearing to be overlapping but at the same time narrowing Ondoafi's space as the customary head of the implementation of the task, which is originally responsible to the ancestors and their people, must now also be responsible to the regents or regional governments. This responsibility carries large legal consequences.

\section{Bibliography}

Badan Penelitian dan Pengembangan Daerah Kabupaten Jayapura, The Role of Ondoafi between the Modern State and the New "Religions" (Peran Ondoafi yang Terapit antara Negara Modern dan "Agama-Agama" Baru). Delivered in Socialization of the Role of Ondoafi in Jayapura, 2013.

Bayu Surianingrat, Village Government and Administration (Pemerintahan dan Administrasi Desa), Yayasan Beringin Korpri Unit Departemen Dalam Negeri, Jakarta, 1976.

Bushar Muhammad, The Basics of the Customary Law (Pokok-Pokok Hukum Adat), Pradnya Paramita, Jakarta 2000

Hilman Hadikusuma, Customary Administrative Law (Hukum Ketatanegaraan Adat), Alumni, Bandung 1981.

Jimly Asshiddiqie, Principles of Indonesian Constitutional Law Post Reformation (Pokok-Pokok Hukum Tata Negara Indonesia Pasca Reformasi), PT Bhuana Ilmu Populer, Jakarta, 2007.

Joshz Mansoben, Diversity of Leadership Systems in Irian Jaya Province, in Yulfita Raharjo (ed.), Proceedings on Building Irian Jaya Communities (Kebinekaan Sistem Kepemimpinan Di Pronvinsi Irian Jaya, dalam Yulfita Raharjo (edt), Proseding Membangun Masyarakat Irian Jaya), Puslitbang Kependudukan dan Ketenagakerjaan Lembaga Ilmu Pengetahuan Indonesia (PPT-LIPI), Jakarta, 1995.

Mochtar Kusumaatmadja, Function and Development of Law in National Development (Fungsi dan Perkembangan Hukum Dalam Pembangunan Nasional), Padjadjaran Magazine, in Bernard Arief Sidharta, Reflection Regarding Structure of Legal Science (Refleksi Tentang Struktur Ilmu Hukum), Maju Mandar, Bandung, 2009.

Mochtar Kusumaatmadja and Arief Sidharta, Introduction to Legal Studies: A First Introduction to the Scope of Applicability to Legal Studies (Pengantar Ilmu Hukum Suatu Pengenalan Pertama Ruang Lingkup Berlakunya Ilmu Hukum), Buku I, Penerbit Alumni, Bandung, 2000.

Moh. Mahfud MD, Building Political Law, Upholding the Constitution (Membangun Politik Hukum, Menegakkan Konstitusi), LP3ES, Jakarta, 2006.

\footnotetext{
${ }^{1}$ Badan Penelitian dan Pengembangan Daerah Kabupaten Jayapura, op.cit., p. 4.
} 
Padmo Wahyono, Indonesia is based on law (Indonesia Negara Berdasarkan Atas Hukum), Ghalia Indonesia, Jakarta 1986.

Soerojo Wignjodipoera, Introduction and Principles of Customary Law (Pengantar dan Asas-Asas Hukum Adat), Penerbit Toko Gunung Agung, Jakarta, 1995.

Sudargo Gautama, Definition of State Law (Pengertian Tentang Negara Hukum), Alumni, Bandung, 1973.

Willem Malowali, The System of Ondofolo Governmnet: some Notes to Amendments as resulted ofImplementation of Governemnt System Based on The Law No. 5 of 1979 (Sistem Pemerintahan Ondofolo; Beberapa Catatan Tentang Perubahan-Perubahan yang terjadi sebagai akibat dari Pelaksanaan Sistem Pemerintahan Berdasarkan Undang-Undang Nomor 5 Tahun 1979), Jayapura,1986. 